\title{
Semiotika Sistem Tanda Roland Barthes Pada Advertising Promosi
}

\author{
Nunik Hariyani ${ }^{1}$ \\ ${ }^{1}$ Universitas Merdeka Madiun, Address Jl. Serayu No.79, Pandean Kec. Taman, Kota Madiun, Jawa Timur, 63133, Indonesia \\ E-mail:nunik@unmer-madiun.ac.id
}

\begin{abstract}
Penelitian ini membahas tentang representasi makna cinta lingkungan dalam iklan Rinso edisi "yuk mulai bijak sampah" yang bertujuan untuk mengetahui bagaimana cinta lingkungan disimbolkan dalam iklan Rinso edisi "yuk mulai bijak plastik". Selain itu, penelitian ini juga bermaksud untuk menginterpretasi makna cinta lingkungan dalam iklan Rinso edisi "yuk mulai bijak plastik". Penelitian ini menggunakan metode analisis teks. Objek yang diteliti adalah iklan Rinso edisi"yuk mulai bijak plastik". Untuk menjawab penelitian digunakan analisis semiologi Roland Barthes. Teknik pengumpulan data dilakukan dengan menggunakan analisis dokumen. Hasil penelitian ini menunjukkan bahwa simbolisasi cinta lingkungan dalam iklan Rinso edisi "yuk mulai bijak plastik" meliputi audio (voice over), dan visual (objek dalam scene, cara pengambilan gambar). Makna cinta lingkungan yang terkandung dalam iklan antara lain yaitu makna dampak kurangnya mencintai lingkungan, lingkungan sebagai tempat seluruh makhluk hidup, pentingnya menjaga lingkungan, bijak dalam menggunakan plastik, mengajarkan sadar lingkungan sejak dini, sikap gotong royong, pentingnya membuang sampah pada tempatnya, dan sadar lingkungan untuk kelanjutan generasi selanjutnya. Adapun mitos dari keseluruhan iklan ini menjelaskan bahwa makna cinta lingkungan adalah sadar, menjaga, dan melestarikan lingkungan tersebut. Implikasi dari penelitian ini adalah agar masyarakat terkhususnya penonton televisi lebih selektif dan kritis dalam memaknai pesan iklan yang ada.
\end{abstract}

Keywords: Makna ; Cinta Lingkungan ; Semiotika ; Iklan Televisi.

\section{PENDAHULUAN}

Hingga saat ini media televisi di Indonesia masih menjadi media yang paling banyak digunakan oleh masyarakat Indonesia. Berdasarkan survey Nielsen consumer media view pada tahun 2017 yang dilakukan di 11 kota di Indonesia, penetrasi televisi masih memimpin dengan 96 persen disusul dengan media luar ruang 53 persen, internet 44 persen, radio 37 persen, koran 7 persen, tabloid dan majalah 3 persen (Nielsen, 2017).

Nielsen adalah perusahaan global yang menyediakan pemahaman komprehensif pada apa yang konsumen tonton (watch) dan beli (buy). Watch menyediakan layanan pengukuran total khalayak di seluruh perangkat di mana isi video, audio dan pesan dikonsumsi; bagi klien media dan agensi periklanan. Berlangsung 2 tahun hingga tahun 2019, menurut data yang didapat peneliti dari badan pusat statistik (BPS) Indonesia 2019. Tercatat proporsi penduduk berumur 5 tahun ke atas yang menonton Televisi yaitu 93,21 sedangkan proporsi individu berumur 5 tahun ke atas yang menggunakan internet yaitu 47,69 (BPS, 2019).

Televisi sebagai media yang masih banyak digunakan oleh masyarakat di Indonesia seringkali mengangkat isu-isu sosial, salah satu isu sosial yang mulai sering muncul adalah tentang kerusakan lingkungan yang diakibatkan karena ketidakpedulian terhadap sampah. Persoalan lingkungan juga harus menjadi tanggung jawab media, paling tidak untuk meningkatkan kepedulian dan pemahaman masyarakat agar mau manjaga dan melestarikan lingkungan. Melalui tayangan televisi, orang yang tidak berpendidikan sekalipun akan dapat memahami pesan apa yang ingin disampaikan. Kepedulian terhadap lingkungan mulai berkembang dalam beberapa tahun terakhir ini. Banyak perusahaan mulai menyuarakan bentuk kepeduliaannya terhadap lingkungan melalui konsep iklan yang mereka buat. menerapkan suatu konsep bisnis baru dengan menerapkan isu-isu mengenai lingkungan. Bagi pihak perusahaan, sebagai bentuk kepedulian perusahaan terhadap lingkungan dilakukan dengan membuat iklan-iklan produk yang memberikan konsep cinta lingkungan. Salah satu perusahaan yang mulai memunculkan kepeduliannya terhadap keadaan lingkungan adalah PT. Unilever Indonesia, Tbk. yang menayangkan iklan Rinso edisi "Yuk Mulai Bijak Plastik" (2019). Rinso adalah merk produk detergen dari PT. Unilever Indonesia, Tbk yang hadir di Indonesia sejak tahun 1970. PT Unilever Indonesia, Tbk. meluncurkan kampanye "Yuk Mulai Bijak Plastik" untuk mengajak masyarakat bersama-sama menjaga alam Indonesia agar tidak tercemar oleh sampah plastik adalah salah satu bentuk kegiatan dalam misi perusahaan. Salah satu cara mengkampanyekanya adalah dengan menayangkan iklan Rinso edisi "Yuk Mulai Bijak Plastik".

Penciptaan iklan yang kreatif, informatif dan persuasif diwajibkan agar produk iklan dapat diterima masyarakat dengan mudah. Iklan mengemas konsep kreatifnya dengan simulasi yang diilustrasikan menggunakan setting semirip mungkin dengan realitas suatu masyarakat agar tujuan pesan dalam iklan itu tercapai, dan serta mampu membuat masyarakat tidak sadar dan merasa bahwa mereka sudah terkena terpaan iklan. Penggunaan unsur kreatif secara verbal maupun nonverbal dengan menggunakan kemasan audio dan visual dalam mengkomunikasikan suatu pesan, terkadang 
membuat pesan iklan tersebut mengandung lebih dari satu makna yang tidak mudah dipahami.

Oleh karena itu, pemahaman pesan dalam suatu iklan oleh konsumen maupun produsen iklan itu sendiri seringkali memiliki interpretasi yang beragam sehingga iklan kemudian bisa menjadi multitafsir atau multi pemaknaan dan bisa terjadi kesenjangan antara pembuat iklan dengan pandangan khalayak yang menonton tayangan iklan tersebut di televisi. Hampir secara keseluruhan penggunaan kata dan kalimat pada narasi iklan menggunakan pemaknaan simbolis yang ditampilkan iklan. Pemaknaan iklan itu sendiri dapat dilakukan dengan mencari makna-makna tanda pada teks yang terdapat dalam gambar (visual) maupun suara (audio) yang bisa dilihat secara implisit atau eksplisit, sadar atau tidak sadar, yang dirasakan sebagai kebenaran atau fantasi, ilmu pengetahuan atau logika umum, dan makna-makna tersebut dibawa melalui tanda pada teks dan visual. Pemikiran pada penggunaan tanda merupakan

hasil pengaruh dari berbagai konstruksi sosial di mana penggunaan tanda itu berada (Kriyantono, 2009). Pada kajian tentang makna cinta lingkungan dalam iklan televisi, yaitu iklan produk Rinso tentunya tidak terlepas dari bentuk kajian budaya (cultural studies) yang dilihat dari aspek komunikasi dan bagaimana penggambaran makna cinta lingkungan melalui pesan komunikasi yang dibangun dengan iklan. Dengan melihat representasi pada narasi iklan, maka perlu dilakukan penemuan makna tanda, termasuk hal-hal yang tersembunyi di balik sebuah tanda.

\section{METODE PENELITIAN}

Penelitian ini menggunakan jenis penelitian kualitatif. Karena menggunakan metode semiotika, maka penelitian ini merupakan bagian dari bentuk analisis isi kualitatif, dimana yang menjadi tujuan utamanya adalah untuk melihat isi komunikasi yang tersirat (Wibowo, 2011).

Metodologi kualitatif adalah prosedur penelitian yang menghasilkan data deskriptif berupa kata-kata tertulis atau lisan dari orang dan perilaku yang dapat diamati (Pawito, 2008). Penelitian kualitatif dilakukan juga untuk mendapatkan pemahaman tentang apa yag dialami oleh peneliti untuk memahami fenomena pemaknaan mengenai cinta lingkungan dalam iklan secara mendalam.

Penelitian ini merupakan analisis teks media dengan menggunakan analisis semiotika model Roland Barthes untuk mengetahui secara detail representasi makna cinta lingkungan dalam iklan Rinso edisi "Yuk Mulai Bijak Plastik", dimana proses pembentukan makna oleh semiotik bersifat intensional dan memiliki motivasi. Teks dalam pengertian paling sederhana adalah kombinasi tanda-tanda. Semiotika teks dalam hal ini tidak berhenti hanya menganalisis tanda (jenis, struktur, makna) secara individu, akan tetapi melingkupi pemilihan tanda-tanda yang dikombinasikan ke dalam kelompok atau pola-pola yang lebih besar (teks) yang di dalamnya direpresentasikan sikap, ideologi, atau mitos tertentu yang melatarbelakangi kombinasi tanda-tanda tersebut (Piliang, 2003).

\begin{tabular}{|c|c|c|}
\hline $\begin{array}{l}\text { 1. Signifer } \\
\text { (Penanda) }\end{array}$ & $\begin{array}{l}\text { 2. Signified } \\
\text { (petanda) }\end{array}$ & \\
\hline \multicolumn{2}{|c|}{$\begin{array}{l}\text { 3. Denotative Sigi } \\
\text { (Tanda Denotatif) }\end{array}$} & \\
\hline \multicolumn{2}{|c|}{$\begin{array}{l}\text { 4. CONMOTATIVE SIGNIFIER } \\
\text { (PENANDA KONOTATIF) }\end{array}$} & $\begin{array}{l}\text { 5. CONNOTATNE SIGNIFIED } \\
\text { (PETANDA KONOTATIF) }\end{array}$ \\
\hline \multicolumn{3}{|c|}{ 6. CONNOTATIVE SIGN (TANDA KONOTATIF) } \\
\hline
\end{tabular}

\section{Gambar 2.1 Peta Tanda Roland Barthes}

Adapun paradigma dalam penelitian ini yaitu paradigma interpretif. Paradigma merupakan perspektif riset yang digunakan peneliti yang berisi bagaimana cara pandang peneliti melihat realita. Paradigma Interpretif adalah salah satu paradigma non positivisme. Pendekatan alternatif ini berasal dari beberapa filsuf jerman yang memfokuskan penelitian pada peranan bahasa, interpretasi dan pemahaman dalam ilmu sosial. Hakikat interpretif ini menganggap individu melihat dan membangun realitas sosial secara aktif dan sadar, sehingga setiap individu pasti memiliki pemaknaan yang berbeda pada suatu peristiwa, dengan kata lain realitas sosial adalah hasil bentukan dari serangkaian interaksi antar pelaku sosial dalam sebuah lingkungan. Di dalam pardigma interpretif, ilmu pengetahuan dianggap 
sebagai cara untuk memahami (to understand) suatu peristiwa (Burrel \& Gareth, 1979).

Dalam penelitian ini peneliti menyikapi peristiwa isu sosial yang ada dalam iklan Rinso berdasarkan makna yang peneliti tersebut buat sendiri, makna terbentuk karena adanya interaksi sosial yang dijalin dengan individu lain, Makna yang di dapat ataupun terbentuk akan dipahami dan di modifikasi oleh peneliti melalui proses interpretif yang juga berkaitan dengan hal lain yang dihadapinya."

\section{HASIL DAN PEMBAHASAN}

Setelah dilakukan pengamatan berulang kali terhadap iklan, peneliti menemukan scene-scene yang mengandung makna cinta laingkungan dalam iklan Rinso edisi "Yuk Mulai Bijak Plastik", kemudian akan peneliti sajikan menjadi delapan scene pilihan.

Scene pilihan tersebut dimasukan kedalam tabel analisis semiotika roland barthes, kemudian di identifikasi penanda dan petandanya sehingga menjadi sebuah makna denotatif. Kemudian dilanjutkan pemaknaan yang kedua yaitu makna konotatif, makna konotatif adalah makna denotatif ditambah dengan segala gambaran, ingatan, perasaaan, emosi, serta nilai-nilai dari kebudayaan pengamat tanda. Dalam kerangka barthes konotasi mengandung mitos didalamnya, atau bisa disebut juga makna yang memiliki "sejarah budaya di belakangnya" yaitu bahwa ia hanya bisa dipahami dalam kaitannya dengan signifikansi tertentu.

Setelah pemaknaan konotasi yang di dalamnya terdapat mitos, kemudian peneliti menggunakan representasi, yaitu memaknai kembali sebagai cara untuk melihat mitos, sikap, atau nilai budaya apa saja yang ingin iklan tersebut sampaikan dalam makna cinta lingkungan.

\subsection{Scene pilihan 1}

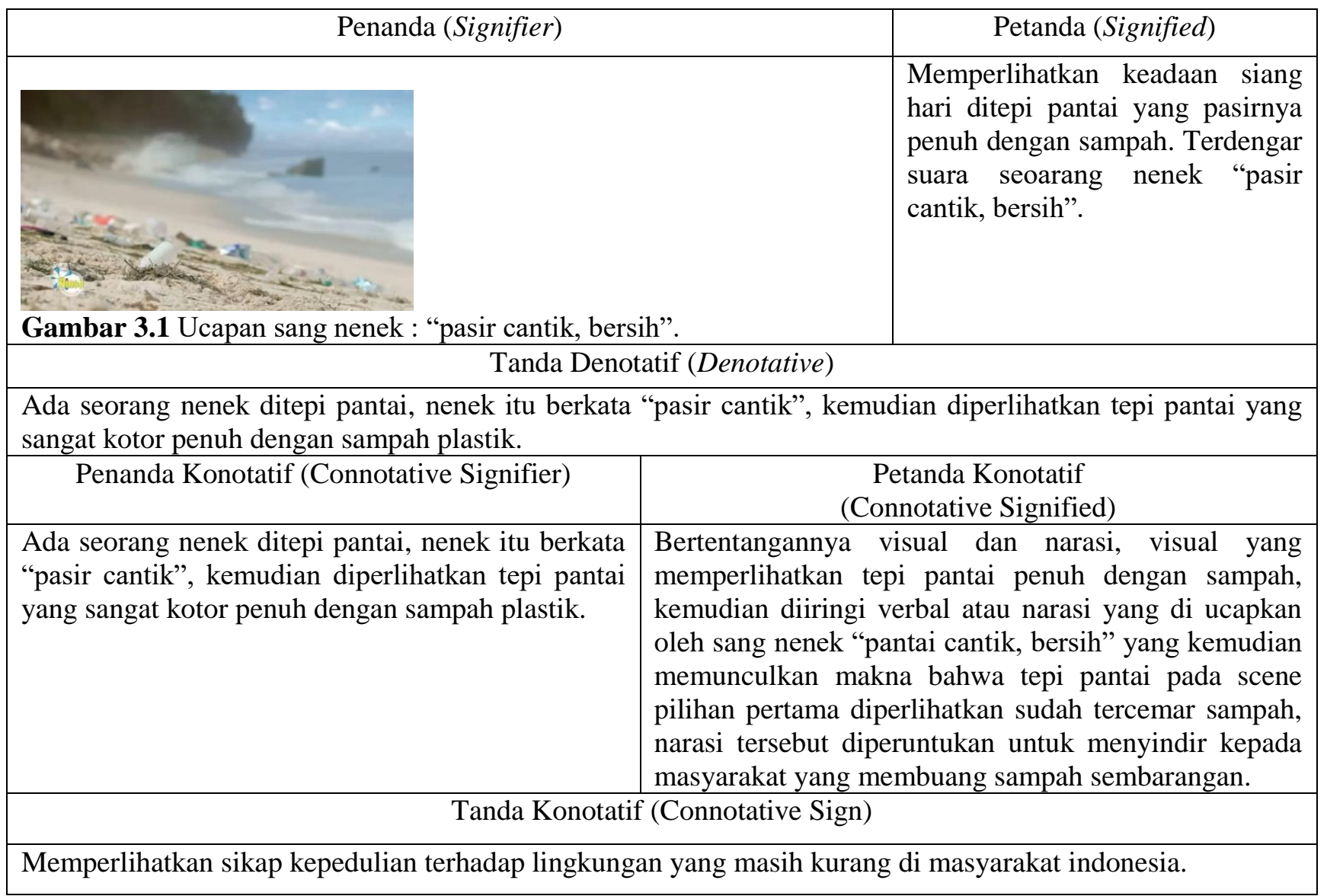




\subsubsection{Representasi dampak kurangnya peduli lingkungan}

Scene pilihan pertama bertujuan untuk memperlihatkan akibat banyak masyarakat yang tidak sadar untuk mencintai lingkungan terlihat sampah-sampah yang mencemari tepi pantai. dilihat dari yang ditampilkan dan apa yang dinarasikan bertentangan, ketika apa yang dikatakan tidak sesuai dengan apa yang diperlihatkan maka kalimat tersebut adalah kritik halus / majas ironi untuk mengungkapkan sindiran halus yakni dengan menggunakan kata-kata yang bertentangan dengan makna sesungguhnya. Kritikan yang disampaikan scene ini tertuju kepada masyarakat yang masih belum memiliki kesadaran dalam menjaga lingkungan. Keterkaitan scene iklan rinso ini dengan fungsi dasar periklanan adalah sebagai pengalaman buatan, scene yang diperlihatkan semirip mungkin yaitu rinso memperlihatkan tepi pantai yang mulai banyak tercemar oleh sampah plastik, dari latar belakang penelitian kita bisa melihat setiap tahun sampah indonesia terus bertambah menurut data yang di paparkan oleh KLHK. Pada scene ini rinso menggunakan periklanan untuk penyebaran informasi tentang peristiwa (Classified Advertising) (Saladin, 2011). Audio (narasi sang nenek) "pasir cantik, bersih" kemudian visual diperlihatkan pengambilan gambar long shot pada pada adegan pertama bertujuan untuk memperlihatkan sampah sebagai subjek. Maka dapat di representasikan rinso dalam scene ini ingin memperlihatkan kepada penonton, tepi pantai yang tercemar akibat masih banyak orang yang membuang sampah sembarangan dengan pandangan sang nenek beserta cucunya ditepi pantai tersebut.

Cinta lingkungan atau kesadaran lingkungan, ialah usaha melibatkan setiap warga negara dalam menumbuhkan dan membina kesadaran untuk melestarikan lingkungan, berdasarkan tata nilai, yaitu tata nilai daripada lingkungan itu sendiri dengan filsafat hidup secara dalam dengan alam lingkungannya (Syaprillah, 2018).

Pada scene pertama ini juga rinso berusaha membuat atau mengkontruksi realitas sosial secara media (iklannya) kepada penontonnya bahwa, lingkungan benar-benar sudah tercemar. Mengingat sifat dan fakta pekerjaan media massa adalah menceritakan peristiwa-peristiwa, maka kesibukan utama media massa adalah mengkonstruksi berbagai realitas yang akan disiarkan. Media menyusun realitas dari berbagai peristiwa yang terjadi hingga menjadi cerita atau wacana yang bermakna. Jadi dapat disimpulkan, seluruh isi media tiada lain adalah realitas yang telah dikonstruksikan (constructed reality) dalam bentuk wacana yang bermakna.

\subsection{Scene pilihan 2}

\begin{tabular}{|c|c|c|}
\hline \multicolumn{2}{|l|}{ Penanda (Signifier) } & Petanda (Signified) \\
\hline Gambar 3.2 Ucapan sang nenek : "ikan warna-warn & ia itu indah loh". & $\begin{array}{l}\text { Gambar } 3.2 \text { terlihat ikan yang } \\
\text { sedang berenang dengan keadaan } \\
\text { laut yang banyak sampah plastik. } \\
\text { Sambil terdengar ucapan sang } \\
\text { nenek "ikan warna-warni" } \\
\text { Gambar } 3.3 \text { memperlihatkan } \\
\text { seekor anak penyu yang berjalan } \\
\text { ditepi pantai terbalik akibat ingin } \\
\text { melewati sampah plastik. Diiringi } \\
\text { ucapan sang nenek "dari dulu } \\
\text { indonesia itu indah loh". }\end{array}$ \\
\hline \multicolumn{3}{|c|}{ Tanda Denotatif (Denotative) } \\
\hline \multicolumn{3}{|c|}{$\begin{array}{l}\text { Bertentangannya ucapan sang nenek dengan adegan yang ditampilkan menimbulkan pemahaman bahwa } \\
\text { pemandangan tepi pantai itu yang dulunya indah menurut si nenek ternyata telah tercemar, diperlihatkan ikan } \\
\text { yang berenang dan penyu yang berjalan terbalik akibat berusaha melewati tumpukan sampah plastik. }\end{array}$} \\
\hline Penanda Konotatif (Connotative Signifier) & \multicolumn{2}{|c|}{$\begin{array}{c}\text { Petanda Konotatif } \\
(\text { Connotative Signified })\end{array}$} \\
\hline $\begin{array}{l}\text { Bertentangannya ucapan sang nenek dengan adegan } \\
\text { yang ditampilkan menimbulkan pemahaman bahwa } \\
\text { pemandangan tepi pantai itu yang dulunya indah }\end{array}$ & \multicolumn{2}{|c|}{$\begin{array}{l}\text { keadaan tepi pantai yang menjadi habitat asli anak } \\
\text { penyu telah tercemar oleh banyaknya sampah plastik } \\
\text { yang dibuang sembarangan oleh masyarakat, ikan-ikan }\end{array}$} \\
\hline
\end{tabular}




\begin{tabular}{|l|l|}
\hline $\begin{array}{l}\text { menurut si nenek ternyata telah tercemar, } \\
\text { diperlihatkan ikan yang berenang dan penyu yang } \\
\text { berjalan terbalik akibat berusaha melewati } \\
\text { tumpukan sampah plastik. }\end{array}$ & $\begin{array}{l}\text { beserta anak penyu tersebut menjadi terlihat } \\
\text { menyedihkan karena berusaha bertahan hidup dikondisi } \\
\text { habitatnya yang rusak. Kepedulian manusia terhadap } \\
\text { lingkungan sangatlah penting, karena yang hidup di } \\
\text { dunia bukan hanya manusia saja tetapi hewan-hewan } \\
\text { yang habitat aslinya adalah alam. }\end{array}$ \\
\hline $\begin{array}{l}\text { semua makhluk hidup bergantung pada lingkungan, seharusnya manusia yang mempunyai akal lebih dapat } \\
\text { menjaga lingkungan. }\end{array}$ \\
\hline
\end{tabular}

\subsubsection{Representasi lingkungan sebagai habitat makhluk hidup}

Scene pilihan kedua bertujuan untuk memperlihatkan akibat banyaknya sampah yang mencemari lingkungan, banyak hewan-hewan terkena dampaknya, karena lingkungan sendiri adalah tempat hidup/ habitat asli untuk flora maupun fauna.

Pada scene kedua ini menggunakan pengambilan gambar Long Shoot dengan memperlihatkan ikan yang berenang bersama sampah plastik, kemudian pada Gambar 3.3 juga memperlihatkan pengambilan gambar Long Shoot penyu dan sampah plastik sebagai objek dengan pasir tepi pantai sebagai latar belakang, penyu itu seolah sedang berjalan kemudian terbalik akibat berusaha melewati tumpukan sampah. Dengan diperlihatkannya ikan yang berenang di air laut bersama sampah, kemudian penyu yang berjalan di tepi pantai yang penuh dengan sampah, dari dua hal ini dapat diartikan jika hewan-hewan tersebut habitatnya terganggu. Ikan yang berenang di laut bersama sampah-sampah kemudian anak penyu yang berjalan di tepi pantai yang penuh dengan sampah menginterpretasikan bahwa lingkungan yang menjadi habitat hewan-hewan tersebut telah tercemar sampah, sampah-sampah yang mencemari lingkungan pastilah karena perbuatan manusia yang belum mengerti pentingnya mencintai lingkungan.

Pada scene kedua ini selain terdapat tanda berupa visual terdapat juga tanda audio yaitu sang nenek berucap "ikan warna-warni", "dari dulu indonesia itu indah loh". Ucapan sang nenek "ikan warna-warni " menurut kbbi warna-warni memiliki persamaan kata yaitu bermacam-macam. Maka dapat di interpretasikan ikan yang berenang bermacammacam, kemudian kalimat berikutnya yaitu "dari dulu indonesia itu indah loh" dapat diartikan bahwa sang nenek bercerita kepada cucunnya pada keadaan dulu bahwa, dari dulu pantai tersebut pemandangannnya nampak indah.

Visual yang tampilkan dan narasi yang di ucapkan sang nenek nampaknya bertentangan. Dari kebertentangan ini kemudian terdapat pengertian bahwa pada scene tersebut pantai yang nenek ceritakan pada masa lalu indah itu sekarang nampaknya sudah tercemar. Ketika ucapan tidak sesuai dengan apa yang terlihat maka sebenernya narasi tersebut dapat berupa sindiran halus. Lebih tepatnya adalah majas ironi, majas ironi adalah mengungkapkan sindiran halus yakni dengan menggunakan kata-kata yang bertentangan dengan makna sesungguhnya. Sindiran halus atau kritikan ini ditujukan kepada orang-orang yang belum sadar akan pentingnya menjaga lingkungan, peneliti sendiri ketika melihat scene ini mengartikan bahwa ini ditujukan agar masyarakat yang tadinya tak memahami pentingnya cinta lingkungan agar menjadi sadar akan pentingnya menjaga lingkungan. Ikan-ikan dan anak penyu yang diperlihatkan pada scene ini diartikan sebagai perwakilan fauna, dan dan tepi pantai serta laut diartikan sebagai perwakilan lingkungan, kemudian sampah-sampah yang yang mencemari lingkungan diartikan sebagai salah satu dampak tidak pedulinya terhadap lingkungan.

\subsection{Scene pilihan 3}

\begin{tabular}{|l|l|}
\hline \multicolumn{1}{|c|}{ Penanda (Signifier) } & \multicolumn{1}{|c|}{ Petanda (Signified) } \\
\hline Gambar 3.4 Ekpresi Bingung & $\begin{array}{l}\text { Gambar 3.4 memperlihatkan } \\
\text { sang cucu yang kebingungan } \\
\text { dengan apa yang sang nenek } \\
\text { ucapkan. } \\
\text { Dari gambar 3.5 dapat dilihat } \\
\text { nenek tersebut tersenyum } \\
\text { sambil berbicara kepada } \\
\text { cucunya itu ternyata sudah } \\
\text { mengalami kebutaan. Terlihat } \\
\text { sang nenek sambil memegang } \\
\text { tongkat untuk tunanetra. }\end{array}$ \\
\hline
\end{tabular}




\begin{tabular}{|c|c|}
\hline $\begin{array}{l}\text { Gambar 3.5 Ucapan sang nenek : "eyang ingin } \\
\text { menikmatinya". }\end{array}$ & kamu juga bisa \\
\hline Tanda Denotatif & (Denotative) \\
\hline $\begin{array}{l}\text { Cucu yang kebingungan karena sebelumnya mendenga } \\
\text { bersih dan cantik. Karena sang nenek mengalami kebuta } \\
\text { yang dilihat cucunya saat itu sudah tercemar oleh sampal }\end{array}$ & $\begin{array}{l}\text { I perkataan sang nenek bahwa tepi pantai tersebut } \\
\text { an, sang nenek tidak tahu bahwa keadaan tepi pantai } \\
\text { h plastik. }\end{array}$ \\
\hline Penanda Konotatif (Connotative Signifier) & $\begin{array}{c}\text { Petanda Konotatif } \\
(\text { Connotative Signified })\end{array}$ \\
\hline $\begin{array}{l}\text { Cucu yang kebingungan karena sebelumnya mendengar } \\
\text { perkataan sang nenek bahwa tepi pantai tersebut bersih } \\
\text { dan cantik. Karena sang nenek mengalami kebutaan, } \\
\text { sang nenek tidak tahu bahwa keadaan tepi pantai yang } \\
\text { dilihat cucunya saat itu sudah tercemar oleh sampah } \\
\text { plastik. }\end{array}$ & $\begin{array}{l}\text { Keindahan pantai tersebut kala dulu tidak bisa } \\
\text { dilihat oleh sang cucu karena sekarang pantai } \\
\text { tersebut penuh dengan sampah plastik. Banyaknya } \\
\text { sampah plastik yang mencemari pantai tersebut } \\
\text { saat ini dapat diartikan bahwa masih belum banyak } \\
\text { yang peduli untuk menjaga lingkungan, dengan } \\
\text { tidak membuang sampah sembarangan. }\end{array}$ \\
\hline Tanda Konotatif $(\mathrm{Cc}$ & onnotative Sign) \\
\hline
\end{tabular}

\subsubsection{Representasi pentingnya sikap menjaga lingkungan.}

Scene pilihan ketiga bertujuan untuk memperlihatkan pentingnya sikap menjaga lingkungan. Pada scene ketiga ini menggunakan pengambilan gambar Close Up, tipe pengambilan gambar ini biasanya digunakan untuk menekankan emosi subjek dengan mengambil hanya bagian kepala saja. Close up dapat menampilkan detail pada adegan sehingga penonton dapat ikut merasakan emosi yang ingin disampaikan. Terlihat ekspresi sang cucu yang kebingungan dengan apa yang sang nenek telah ucapkan. Kemudian pada Gambar 3.5 menggunakan pengambilan gambar yang sama yaitu Close Up tujuannya yaitu untuk memperlihatkan ekspresi tersenyum sang nenek. Dengan diperlihatkannya ekspresi kebingungan sang cucu kemudian diperlihatkan juga wajah sang nenek yang berekspresi tersenyum, sang nenek ternyata telah mengalami kebutaan, diperlihatkan dengan pupil mata yang berwarna putih dan sang nenek seolah sedang memegang tongkat untuk tunanetra. Dari dua gambar yang terlihat ini dapat diartikan bahwa pantas saja ucapan sang nenek yang sebelumnya tidak dimengerti oleh cucunya, sang nenek pun tidak tahu dengan kondisi tepi pantai saat itu ketika bersama cucunya, bahwa tepi pantai yang apa yang nenek ceritakan itu pasirnya cantik, bersih seolaholah pemandangannya indah itu ternyata sekarang telah tercemar oleh banyak sampah.

Pada scene ketiga ini terdengar narasi sang nenek yaitu "eyang ingin kamu juga kamu juga bisa menikmatinya". Kalimat tersebut dapat diinterpretasikan bahwa kata "ingin" adalah harapan sang nenek agar cucunya bisa menikmati juga keindahan pantai yang dimaksudkan dalam benak sang nenek tersebut. Harapan atau keinginan sang nenek dalam iklan tersebut mewakili orang-orang yang sadar lingkungan. Karena sadar lingkungan salah satunya adalah dengan melestarikan lingkungan tersebut, melestarikan adalah salah satu bentuk akan sadar lingkungan tujuan dari melestarikan sendiri ialah untuk mempertahankan lingkungan tersebut untuk generasi-genari selanjutnya kelak. Sang cucu tersebut mewakili orang-orang yang belum akan sadarnya menjaga lingkungan, dan juga tentu menjadi generasi selanjutnya dalam kehidupan ini.

Scene ketiga bertujuan untuk mengajak kepada penonton iklan Rinso edisi "yuk mulai bijak plastik" untuk mulai sadar lingkungan. Karena sejak dahulu lingkungan di indonesia itu sangatlah indah. Faktor ketidaktahuan "tidak-tahu" berlawanan dengan kata "tahu". "Sadar" dan "tahu" itu sama (sadar = tahu). Jadi apabila berbicara tentang ketidaktahuan maka hal itu juga membicarakan ketidaksadaran. Seseorang yang tahu akan arti pentingnya lingkungan sehat bagi makhluk hidup, maka orang tersebut akan senantiasa menjaga dan memelihara lingkungan. Salah satu upaya agar masayarakat sadar akan pentingnya lingkungan, maka perlu memunculkan pemikiran akan pentingnya sadar lingkungan dengan memanfaatkan kemajuan teknologi. Sama seperti iklan Rinso edisi "yuk mulai bijak plastik" yang 
dalam scene ini menampilkan seoarang nenek dan cucunya yang sedang berada ditepi pantai, namun sang nenek itu tidak tahu bahwa pantai yang dulunya bersih dan indah semasa ia belum mengalami kebutaan itu kini telah tercemar oleh banyaknya sampah, kemudian sang nenek berbicara kepada cucunya "eyang ingin kamu juga bisa menikmatinya" dengan ekspresi tersenyum. Hal ini jelas bertujuan agar kesadaran lingkungan yang iklan rinso ingin sampaikan dapat terus dimengerti oleh masyarakat indonesia yang belum sadar akan pentingnya sikap menjaga lingkungan.

\subsection{Scene pilihan 4}

\begin{tabular}{|l|l|}
\hline \multicolumn{1}{|c|}{ Penanda (Signifier) } & \multicolumn{1}{c|}{ Petanda (Signified) } \\
\hline Gambar 3.6 Backsound wanita : "Yuk mulai langkah kecil bijak plastik & $\begin{array}{l}\text { Gambar 3.6 memperlihatkan sang } \\
\text { nenek dan cucunya berpegangan } \\
\text { tangan. }\end{array}$ \\
bersama Rinso". \\
\hline $\begin{array}{l}\text { Adanya ajakan untuk mulai bijak plastik bersama Rinso yang diikuti dengan adegan nenek dan cucu yang } \\
\text { berpegangan tangan. }\end{array}$ \\
\hline $\begin{array}{l}\text { Penanda Konotatif (Connotative Signifier) } \\
\text { Tdanya ajakan untuk mulai bijak plastik bersama } \\
\text { Rinso yang diikuti dengan adegan nenek dan cucu } \\
\text { yang berpegangan tangan. }\end{array} \begin{array}{l}\text { Bahwa Rinso dalam iklannya ini bertujuan untuk } \\
\text { membuat citra perusahaan yang peduli terhadap } \\
\text { lingkungan. }\end{array}$ \\
\hline \multicolumn{2}{|c|}{ Tanda Konotatif (Connotative Sign) } \\
\hline Memperlihatkan ajakan sikap untuk bijak plastik.
\end{tabular}

3.4.1 Representasi bijak dalam menggunakan plastik.

Scene pilihan keempat ini bertujuan untuk menyampaikan ajakan dalam menggunakan plastik harus lebih bijak. Dengan menggunakan pengambilan gambar Extreem Close Up scene ini bertujuan menampilkan detail objek terlihat jelas yaitu tangan sang nenek yang bergenggaman dengan tangan sang cucu. Dalam scene ini diperlihatkan seolah sang cucu yang mengajak bergenggaman, terlihat telapak tangan sang cucu yang menghadap keatas.

Kemudian pada scene ini terdengar narasi berupa suara wanita yaitu "Yuk mulai langkah kecil bijak plastik bersama Rinso". "Yuk" dalam kamus besar bahasa Indonesia berarti mengajak atau sama dengan kata "ayo", "langkah" dalam kamus besar bahasa Indonesia berarti gerakan kaki, sikap atau perbuatan. Jadi dari narasi "yuk mulai langkah kecil bijak plastik bersama Rinso" bisa kita artikan bahwa Rinso mengajak kepada penontonnya untuk mulai berbuat bijak dalam menggunakan plastik. Dari data KLHK diketahui bahwa sampah plastik menempati posisi kedua dari banyaknya sampah yang ada di Indonesia. Sampah plastik sendiri adalah sampah yang sangat susah untuk diuraikan oleh bakteri pengurai, jika tidak bijak dalam menggunakan plastik maka sampah plastik tersebut jelas akan mencemari lingkungan.

Salah satu upaya agar sampah plastik tidak kian semakin banyak, yaitu dengan mulai bijak plastik. Mengajak menggunakannya secara bijak dengan memanfaatkan kemajuan teknologi "yaitu iklan televisi karena iklan televisi salah satu fungsinya yaitu untuk mempersuasif masyarakat".

\subsection{Scene pilihan 5}

Penanda (Signifier)

Petanda (Signified) 


\begin{tabular}{|c|c|c|}
\hline \multicolumn{2}{|c|}{$\begin{array}{l}\text { Gambar 3.7 Backsound wanita : "jaga alam tempat bermain untuk anak } \\
\text { kita". }\end{array}$} & $\begin{array}{l}\text { Gambar } 3.7 \text { memperlihatkan } \\
\text { anak anak di tepi pantai pada } \\
\text { hari yang cerah sedang bermain } \\
\text { dan juga sembari memunguti } \\
\text { sampah yang berserakan ditepi } \\
\text { pantai. Ekspresi anak-anak } \\
\text { tersebut terlihat senang. }\end{array}$ \\
\hline \multicolumn{3}{|c|}{ Tanda Denotatif (Denotative) } \\
\hline \multicolumn{3}{|c|}{ Anak-anak yang terlihat senang karena bermain di tepi pantai sembari memunguti sampah. } \\
\hline Penanda Konotatif (Connotative Signifier) & \multicolumn{2}{|c|}{$\begin{array}{c}\text { Petanda Konotatif } \\
(\text { Connotative Signified })\end{array}$} \\
\hline $\begin{array}{l}\text { Anak-anak yang terlihat senang karena bermain di } \\
\text { tepi pantai sembari memunguti sampah. }\end{array}$ & \multicolumn{2}{|c|}{$\begin{array}{l}\text { Kesadaran mencintai lingkungan bisa tumbuh sejak } \\
\text { dini, apa yang anak-anak lihat akan cenderung diikuti } \\
\text { oleh mereka. Oleh karena itu peran orang dewasa dan } \\
\text { media untuk mengajarkan serta memberi contoh untuk } \\
\text { mencintai lingkungan sangatlah penting. }\end{array}$} \\
\hline \multicolumn{3}{|c|}{ Tanda Konotatif (Connotative Sign) } \\
\hline
\end{tabular}

\subsubsection{Representasi mengajarkan anak mencintai lingkungan.}

Scene ini bertujuan untuk memberi tahu kepada kita bahwa pentingnya mengajarkan cinta lingkungan dari kecil. Scene kelima ini menggunakan pengambilan gambar group Shot, pengambilan gambar ini digunakan untuk memperlihatkan sekelompok orang (anak-anak) yang bermain ditepi pantai sambil memunguti sampah. Awalnya diperlihatkan sang cucu yang memunguti sampah sendiri, kemudian ada anak lain yang melihat sang cucu tersebut, akhirnya anak lain itu pun mengajak teman-teman lainnya yang sedang bermain ditepi pantai untuk turut dalam membantu membersihkan sampah. Anak kecil adalah manusia yang masih berpikiran polos, dan cenderung akan mudah mengikuti apa yang ia lihat, dari scene ini terlihat anak-anak yang bermain ditepi pantai menginterpretasikan bahwa alam adalah tempat bermain untuk anak-anak.

Pada scene pertama selain terdapat tanda visual yang berupa anak-anak yang memunguti sampah terdapat pula narasi dengan suara wanita yaitu "jaga alam tempat bermain untuk anak kita". Dari narasi tersebut kemudian peneliti mencoba menginterpretasikan bahwa "jaga alam" memiliki kesamaan dengan menjaga lingkungan atau mencintai lingkungan, karena kata "alam" dalam kamus besar bahasa Indonesia yaitu dapat berarti "lingkungan kehidupan" atau "segala sesuatu yang termasuk dalam satu lingkungan". Dengan begitu narasi tersebut dapat dimaknai juga dengan bahwa lingkungan adalah tempat bermain untuk anak-anak.

Scene ini bertujuan untuk memberi tahu kepada penonton iklan Rinso edisi "yuk bijak plastik" bahwa pentingnya kesadaran lingkungan dapat diajarkan sejak kecil, anak-anak dalam scene ini adalah sebagai generasi penurus kita. Dari tanda visual maupun audio pada scene ini juga terlihat bahwa alam adalah tempat bermain untuk anak-anak, karena banyak hal-hal baik yang bisa didapat anak-anak dari bermain di alam. Seperti ketika bermain di alam bebas, anak akan dihadapkan dengan berbagai hal baru yang tidak diduga sebelumnya. Di sinilah kemampuan anak untuk mengambil keputusan dan mengukur risiko akan dilatih. Misalnya ketika bermain di pantai anak melihat ada kepiting. Awalnya si kecil mungkin merasa takut. Namun, jika diajarkan bahwa kepiting tidak berbahaya selama tidak diganggu, lama-lama anak mampu membangun keberanian dan rasa percaya diri untuk menjelajahi lingkungannya meskipun ada risiko kotor atau digigit serangga dll.

3.6 Scene pilihan 6

\begin{tabular}{|l|c|}
\hline Penanda (Signifier) & Petanda (Signified) \\
\hline
\end{tabular}




\begin{tabular}{|c|c|c|}
\hline $\begin{array}{l}\text { Gambar 3.8 Backsound wanita : "Langkah kecil bija } \\
\text { besar jika semua beraksi". }\end{array}$ & k plastik berdampak & $\begin{array}{l}\text { Gambar } 3.8 \text { memperlihatkan } \\
\text { anak-anak bersama orang tua, } \\
\text { bersama-sama membersihkan } \\
\text { sampah di tepi pantai. }\end{array}$ \\
\hline $\begin{array}{ll}\text { Tanda Denot } \\
\end{array}$ & atif (Denotative) & \\
\hline $\begin{array}{l}\text { Ajakan untuk mencintai lingkungan dengan memula } \\
\text { kalangan baik anak-anak atau dewasa. }\end{array}$ & langkah kecil seperti & memungut sampah kepada semua \\
\hline Penanda Konotatif (Connotative Signifier) & $\begin{array}{r}\mathrm{Pe} \\
(\mathrm{Con}\end{array}$ & $\begin{array}{l}\text { tanda Konotatif } \\
\text { notative Signified) }\end{array}$ \\
\hline $\begin{array}{l}\text { Ajakan untuk mencintai lingkungan dengan } \\
\text { memulai langkah kecil seperti memungut sampah } \\
\text { kepada semua kalangan baik anak-anak atau } \\
\text { dewasa. }\end{array}$ & $\begin{array}{l}\text { Dalam iklannya in } \\
\text { kalangan untuk } \\
\text { melakukan aksi ke } \\
\text { adegan iklan rinso te }\end{array}$ & $\begin{array}{l}\text { i rinso ingin mengajak semua } \\
\text { mencintai lingkungan dengan } \\
\text { ecil yang dikampanyekan pada } \\
\text { rsebut. }\end{array}$ \\
\hline $\begin{array}{ll}\text { Tanda Konotatif }\end{array}$ & (Connotative Sign) & \\
\hline
\end{tabular}

\subsubsection{Representasi Sikap Gotong Royong.}

Scene keenam bertujuan untuk mengkonstruksi budaya kita, budaya gotong royong. gotong royong dalam budaya indonesia adalah bekerja bersama-sama untuk mencapai suatu hasil yang didambakan. Terlihat dalam scene ini menggunakan pengambilan gambar group Shot, pengambilan gambar ini digunakan untuk memperlihatkan sekelompok orang (anak-anak beserta orang tua) yang sedang memunguti sampah-sampah di tepi pantai. dapat diinterpretasikan dari visual scene ini bahwa anak-anak yang sedang bermain ditepi pantai tadi bersama-sama dengan orang tuanya untuk memunguti sampah yang berada ditepi pantai tersebut.

Kemudian pada scene ini terdapat juga narasi berupa suara wanita yaitu "Langkah kecil bijak plastik berdampak besar jika semua beraksi". Seperti sebelumnya bahwa kata "langkah kecil" dapat diartikan juga "berbuat". Maka kalimat narasi wanita pada scene ini dapat di interpretasikan, berbuat hal kecil dalam bijak menggunakan plastik dapat berdampak besar jika banyak masyarakat yang beraksi.

Dengan diperlihatkannya adegan anak-anak dan orang tua yang memunguti sampah plastik serta diiringi narasi "Langkah kecil bijak plastik berdampak besar jika semua beraksi' iklan tersebut bertujuan, untuk mengkonstruksi budaya gotong royong tertama dalam hal menjaga lingkungan. Pada kenyataannya dikehidupan sosial, hal yang dilakukan bersamaan akan lebih mudah dan tidak menguras banyak tenaga tiap individu. Salah satu tujuan dalam hal gotong royong yang dilakukan masyarakat indonesia yaitu mengajak setiap individu untuk bekerja sama dalam memecahkan suatu permasalahan ataupun menjaga suatu lingkungan, menjaga atau mencintai lingkungan demi kebersihan dan kenyamanan lingkungan merupakan salah satu manfaat dalam bergotong royong.

\subsection{Scene pilihan 7}

\begin{tabular}{|l|l|}
\hline \multicolumn{1}{|c|}{ Penanda (Signifier) } & \multicolumn{1}{|c|}{ Petanda (Signified) } \\
\hline Gambar 3.9 Anak-anak membawa sampah & $\begin{array}{l}\text { Gambar 3.9 memperlihatkan } \\
\text { anak-anak yang membawa } \\
\text { sampah yang telah mereka } \\
\text { pungut di tepi pantai untuk } \\
\text { dimasukan ke tong sampah yang } \\
\text { dibantu oleh orang tua. } \\
\text { Pada Gambar 3.10 ada anak-anak } \\
\text { yang memperlihatkan ekspresi }\end{array}$ \\
\hline
\end{tabular}




\begin{tabular}{|c|c|c|}
\hline \multirow{2}{*}{\multicolumn{2}{|c|}{$\begin{array}{l}\text { Gambar 3.10 Backsound wanita : "baju kotor demi kebaikan, ga } \\
\text { masalah" "karena ada Rinso yang bersihkan noda bandel". }\end{array}$}} & $\begin{array}{l}\text { tersenyum dengan bajunya yang } \\
\text { kotor. }\end{array}$ \\
\hline & & \\
\hline \multicolumn{3}{|c|}{ Tanda Denotatif (Denotative) } \\
\hline \multicolumn{3}{|c|}{$\begin{array}{l}\text { Anak-anak yang membawa sampah dengan bajunya untuk dimasukan ke tong sampah tersebut seolah-olah } \\
\text { tidak takut akan kotor. }\end{array}$} \\
\hline Penanda Konotatif (Connotative Signifier) & \multicolumn{2}{|c|}{$\begin{array}{c}\text { Petanda Konotatif } \\
\text { (Connotative Signified) }\end{array}$} \\
\hline $\begin{array}{l}\text { Anak-anak yang membawa sampah dengan bajunya } \\
\text { untuk dimasukan ke tong sampah tersebut seolah- } \\
\text { olah tidak takut akan kotor. }\end{array}$ & \multicolumn{2}{|c|}{$\begin{array}{l}\text { Jangan buang sampah sembarangan buanglah pada } \\
\text { tempatnya diperlihatkan dengan adegan anak-anak } \\
\text { yang memunguti sampah yang berserakan di tepi pantai } \\
\text { kemudian mereka ambil dan masukan kedalam tempat } \\
\text { sampah. Terlihat adegan selanjutnya anak-anak yang } \\
\text { tersenyum setelah membersihkan sampah, dapat di } \\
\text { representasikan mereka tersenyum bahagia karena } \\
\text { pantai yang menjadi tempat mereka bermain telah } \\
\text { bersih dan nyaman. }\end{array}$} \\
\hline \multicolumn{3}{|c|}{ Tanda Konotatif (Connotative Sign) } \\
\hline
\end{tabular}

\subsubsection{Representasi membuang sampah pada tempatnya.}

Scene ketujuh ini bertujuan untuk menyampaikan bahwa membuang sampah haruslah pada tempatnya, karena sampah milik kita adalah tanggung jawab diri kita sendiri. Terdapat tanda visual dengan diperlihatkannya anak-anak yang usai memunguti sampah mewadahi nya dengan baju tersebut kemudian berjalan menuju tempat sampah, yang selanjutnya ketika sampahnya akan dimasukan ketempat sampah anak-anak tersebut dibantu oleh orang tuanya untuk memasukan sampahnya kedalam tempat sampah. Kemudian adegan selanjutnya yaitu terlihat anak-anak dengan bajunya yang kotor karena mewadahi sampah yang mereka kumpulkan, disertai seolah melihat pemandangan dengan ekspresi tersenyum bahagia.

Pada scene ketujuh selain terdapat tanda visual, juga terdapat tanda narasi. Dalam scene ketujuh tanda narasinya yaitu "baju kotor demi kebaikan, ga masalah". Dapat diinterpretasikan jika visual dan narasi digabungkan akan menjadikan pesan bahwa tak perlu takut akan kotor ketika ingin menjaga lingkungan, karena menjaga lingkungan adalah bentuk kebaikan dalam upaya melestarikannya. Salah satu upaya menjaga lingkungan yang terdapat pada scene adalah membuang sampah pada tempatnya. Membuang sampah pada tempatnya dapat membantu menjaga lingkungan, karena sampah yang dibuang pada tempatnya kemudian akan dikumpulkan ditempat pembuangan akhir. Membuang sampah pada tempatnya adalah salah satu bentuk upaya menghindari tindakan-tindakan yang dapat menimbulkan pencemaran, merusak kesehatan dan lingkungan.

Dalam upaya agar membuang sampah pada tempatnya dapat diikuti oleh semua orang, yaitu dengan menggunakan iklan pada televisi, yaitu menampilkan anak-anak yang membawa sampah dengan mewadahinya menggunakan baju kemudian sampah tersebut dimasukan kedalam tempat sampah, yang terdapat pada iklan ini Rinso ingin menyampaikan agar membuang sampah pada tempatnya. Hal ini jelas bertujuan agar iklan tersebut terus dikonsumsi oleh masyarakat Indonesia sehingga sikap membuang sampah pada tempatnya dapat diimplementasikan pada kehidupan sehari-hari. 


\subsection{Scene pilihan 8}

\begin{tabular}{|c|c|c|}
\hline \multicolumn{2}{|l|}{ Penanda (Signifier) } & Petanda (Signified) \\
\hline \multicolumn{2}{|c|}{ Gambar 3.11 Backsound wanita : "rinso, berani kotor demi kebaikan". } & $\begin{array}{l}\text { Gambar } 3.11 \text { memperlihatkan } \\
\text { sang cucu melepaskan anak } \\
\text { penyu yang ia wadahi } \\
\text { ditempurung kelapa, kemudian } \\
\text { anak penyu tersebut seolah } \\
\text { berjalan menuju kemasan produk } \\
\text { detergen rinso yang diatasnya } \\
\text { terdapat tulisan "berani kotor } \\
\text { demi kebaikan". Ekspresi } \\
\text { gembira yang ditunjukan sang } \\
\text { cucu. }\end{array}$ \\
\hline \multicolumn{3}{|c|}{ Tanda Denotatif (Denotative) } \\
\hline \multicolumn{3}{|c|}{$\begin{array}{l}\text { Memperlihatkan ekspresi tersenyum gembira dari sang cucu yang sedang melepaskan anak penyu yang ia } \\
\text { wadahi ditempurung kelapa, kemudian anak penyu tersebut seolah berjalan menuju kemasan produk detergen } \\
\text { rinso yang diatasnya terdapat tulisan "berani kotor demi kebaikan". }\end{array}$} \\
\hline Penanda Konotatif (Connotative Signifier) & \multicolumn{2}{|c|}{$\begin{array}{c}\text { Petanda Konotatif } \\
(\text { Connotative Signified })\end{array}$} \\
\hline $\begin{array}{l}\text { Memperlihatkan ekspresi tersenyum gembira dari } \\
\text { sang cucu yang sedang melepaskan anak penyu yang } \\
\text { ia wadahi ditempurung kelapa, kemudian anak } \\
\text { penyu tersebut seolah berjalan menuju kemasan } \\
\text { produk detergen rinso yang diatasnya terdapat } \\
\text { tulisan "berani kotor demi kebaikan". }\end{array}$ & \multicolumn{2}{|c|}{$\begin{array}{l}\text { Terlihat secara jelas produk rinso dan juga slogannya } \\
\text { "berani kotor demi kebaikan" pada scene ini bertujuan } \\
\text { untuk membuat citra kepada konsumennya, bahwa } \\
\text { rinso sebagai produk detergen di indonesia peduli akan } \\
\text { cinta lingkungan, dapat kita lihat adegan penyu yang } \\
\text { berjalan menghampiri produk detergen rinso } \\
\text { mempersentasikan bahwa rinso turut peduli dalam } \\
\text { menjaga lingkungan sebagai habitat asli hewan-hewan. }\end{array}$} \\
\hline \multicolumn{3}{|c|}{ Tanda Konotatif (Connotative Sign) } \\
\hline
\end{tabular}

3.8.1 Representasi sadar lingkungan untuk generasi kita selanjutnya.

Scene terakhir bertujuan untuk menyampaikan sadar lingkungan untuk generasi selanjutnya, terdapat tanda visual dengan menggunakan pengambilan gambar Medium Close Up untuk memperlihatkan ekspresi tersenyum sang cucu yang sedang melepaskan anak penyu. Sebelumnya pada scene kedua terdapat anak penyu yang berjalan terbalik akibat berusaha melewati tumpukan sampah, kemudian pada scene ini diperlihatkan bahwa anak penyu tersebut diselamatkan oleh sang cucu, ketika sampah disekitar tepi pantai sudah bersih, sang cucu melepaskan kembali anak penyu yang ia selamatkan sebelumnya.

Pada scene terakhir ini terdapat narasi suara wanita yaitu "rinso, berani kotor demi kebaikan". Kalimat berani kotor demi kebaikan dapat dimaknai hampir sama seperti kalimat sebelumnya "baju kotor demi kebaikan, ga masalah", yang berarti tak perlu takut kotor demi menjaga lingkungan. Namun dinarasi ini menyebutkan "Rinso" yang dapat diinterpretasikan bahwa dalam narasi ini. Rinso ingin memberi tahu penontonnya bahwa Rinso turut peduli dalam menjaga lingkungan.

Dari tanda visual dan narasi yang terdapat pada scene ini, jelas bertujuan untuk menyampaikan bahwa pentingnya sadar lingkungan untuk generasi selanjutnya, dengan diperlihatkan sang cucu yang melepas anak penyu, sang cucu dalam iklan ini dapat dimaknai sebagai generasi muda yang sadar lingkungan, kemudian anak penyu yang dilepaskan oleh sang cucu memiliki makna tersendiri, dalam ajaran buddha melepaskan hewan bisa disebut juga sebagai tradisi yang bernama Fang Sheng berasal dari bahasa Tionghoa, Fang berarti melepas dan Shen berarti kehidupan. "Jadi, hewan yang ditangkap kita, dikembalikan ke alam. menurut ajaran Buddha manusia harus menyayangi makhluk hidup termasuk hewan. Tradisi Fang Shen merupakan wujud cinta pada alam dan hewan. Biasanya ketika hari besar keagamaan atau ketika keinginan terwujud, akan dilakukan pelepasan hewan ke alam liar (Sutanto, 2019). sang cucu pada scene ini sebagai generasi muda yang sadar lingkungan, anak penyu dalam scene ini mewakili fauna yang dijaga lingkungannya. 


\section{KESIMPULAN}

Berdasarkan hasil analisis peneliti pada hasil dan diskusi sebelumnya, maka peneliti dapat menarik kesimpulan bahwa iklan Rinso edisi "yuk mulai bijak plastik" dalam makna cinta lingkungan yang ingin disampaikannya terkandung mitos (sikap serta nilai-nilai budaya) yang telah peneliti temukan antara lain ; (1) memperlihatkan sikap kepedulian terhadap lingkungan yang masih kurang di masyarakat indonesia. (2) semua makhluk hidup bergantung pada lingkungan, seharusnya manusia yang mempunyai akal lebih dapat menjaga lingkungan. (3) memperlihatkan sikap pentingnya menjaga lingkungan. (4) memperlihatkan ajakan sikap untuk bijak plastik. (5) memperlihatkan pentinganya mengajarkan sikap cinta lingkungan sejak dini. (6) memperlihatkan kepada penonton iklan tentang budaya gotong royong dalam menjaga lingkungan. (7) memperlihatkan kepada penonton tentang sikap membuang sampah pada tempatnya. (8) memperlihatkan pentingnya sikap sadar lingkungan untuk generasi selanjutnya. Makna cinta lingkungan yang ingin disampaikan Rinso dalam iklan edisi "yuk mulai bijak plastik" memiliki kesamaan secara pengamatan semiotika dan hasil representasi yang telah peneliti lakukan dengan konsep yang ada dalam pikiran peneliti dan terhadap tanda-tanda yang ada dalam iklan Rinso "Yuk Mulai Bijak Plastik" dalam memproduksi makna cinta lingkungan tersebut. Tentunya iklan yang menyampaikan tentang pentingnya cinta lingkungan yang saat ini banyak di iklankan oleh pengiklan bukan hanya karena sekedar trend belaka, tapi memang realitas yang ada bahwa indonesia saat ini lingkungannya banyak tercemar oleh sampah, sesuai dengan apa yang peneliti temukan dari data sampah KLHK.

Peneliti juga dalam iklan yang ditelitinya ini menemukan bahwa Rinso sebagai perusahaan yang mengiklankan iklan tersebut di televisi, tak hanya ingin menyampaikan pentingnya mencintai lingkungan, namun Rinso ingin membuat citra kepada masyarakat yang menonton bahwa mereka adalah perusahaan yang peduli terhadap lingkungan terlihat dari ajakan kampanyenya dan penempatan slogan "berani kotor demi kebaikan". Sesuai dengan apa yang dikatakan oleh (Saladin, 2011) tentang manfaat iklan salah satunya Intitutional Advertising, yaitu periklanan untuk pembentukan citra organisasi atau perusahaan dalam jangka panjang.

\section{DAFTAR PUSTAKA}

Asyhar, \& Rayandra, H. (2013). In Kreatif Mengembangkan Media Pembelajaran. Jakarta: Gaung Persada Press.

Aziz, E. (2013). In Upaya Pelestarian Lingkungan Hidup Melalui Pendidikan Islam. Yogyakarta: Pustaka Pelajar.

Azizah, S. N. (2018). Representasi Tempat Tinggal Ideal Dalam Iklan Meikarta (Studi Pada Iklan "Aku Ingin Pindah Ke Meikarta” di Televisi). Skripsi. Bandar Lampung: Fakultas Ilmu Sosial dan Ilmu Politik Universitas Lampung.

Barthes, R. (2007). In Membedah Mitos-Mitos Budaya Massa: Semiotika atau Sosiologi Tanda, Simbol dan Representasi. Yogyakarta: Jalasutra.

Batey, I. (2003). In W. Abdul (Ed.), Asian Branding : A Great Way to Fly. Jakarta: Bhuana Ilmu Populer.

BPS. (2019). Badan Pusat Statistik. Retrieved November 25, 2020, from http://www.bps.go.id

Budiman, K. (2011). In Semiotika Visual: Konsep, Isu dan Problem Ikonisitas. Yogyakarta: Jalasutra.

Bungin, M. B. (2015). In Konstruksi Sosial Media Massa. Jakarta: Kencana Prenada Media Group.

Burhanudin, D. N. (2019). Pesan Moral Pada Iklan di Televisi (Studi Analisis Semiotik Pada Iklan L.A Lights Edisi Taklukan Tantanganmu). Skripsi. Ponorogo: Jurusan Komunikasi dan Penyiaran Islam Fakultas Ushuluddin Adab dan Dakwah Institut Agama Islam Negeri (IAIN).

Burrel, G., \& Gareth, M. (1979). Sociological Paradigms and Organisational Analysis. London: Heinemann Educational Book Ltd.

Cangara, H. (2011). In Pengantar Ilmu Komunikasi. Jakarta: PT Raja Grafindo Persada.

Danesi, M. (2010). In Pesan, Tanda dan Makna: Buku Teks Dasar Mengenai Semiotika dan Teori Komunikasi. Yogyakarta: Jalasutra.

Darmaprawira, S. (2002). In Warna : Teori dan Kreativitas Penggunaanya edisi ke 2. Bandung: ITB. 
Website : http://sosial.unmermadiun.ac.id/index.php/sosial

Duludu, U. A. (2017). In Buku Ajar Kurikulum Bahan dan Media Pembelajaran PLS. Yogyakarta: Deepublish.

Durianto, D. (2011). In Strategi Menaklukan Pasar Melalui Riset Ekuitas dan Perilaku Merek. Jakarta: PT. Gramedia Pustaka Utama.

Effendi, O. (1981). In Dimensi-Dimensi Komunikasi. Bandung: Alumni.

Effendy, O. U. (2012). In Ilmu Komunikasi Teori dan Praktek. Bandung: PT. Remaja Rosda Karya.

Eriyanto. (2008). In Analisis Wacana. Pengantar Analisis Teks Media. Yogyakarta: PT LKIS Pelangi Aksara Yogyakarta.

Fitriyana, A. N. (2017). Pesan Menjaga Lingkungan Hidup Pada Film "Karbon dalam Ransel" Kajian Analisis Semiotik. Skripsi. Yogyakarta: Jurusan Komunikasi dan Penyiaran Islam Fakultas Dakwah dan Komunikasi Universitas Islam Negeri Sunan Kalijaga.

Habsari, S. U. (2016). Analisa Semiotika Komunikasi Visual Iklan Layanan Masyarakat Lingkungan Hidup. Jurnal PPKM II., III(2), 106-113.

Hall, S. (2003). In The work of representation: "Representation: Cultural Representations and Signifying Practices (Culture, Media and Identities series). london: Sage publication.

Hall, S., Hobson, D., Lowe, A., \& Wilis, P. (2011). Budaya Media dan Bahasa. (s. Rahmania, Trans.) Yogyakarta: Jalasutra.

Haryono, S. R., \& Putra, D. K. (2017). Identitas Budaya Indonesia: Analisis Semiotika Roland Barthes dalam Iklan Aqua Versi “Temukan Indonesiamu. Acta Diurna., 13(2), 67-88.

Hermawan, A. (2012). In Komunikasi Pemasaran. Jakarta: Erlangga.

Jayanthi, R. D. (2017). Makna dan Pesan Iklan Kesehatan "Mencuci Tangan” Pada Media Televisi. LINGUISTIKA. Vol. 24. No. 47. hal. 189-204., 24(47), 189-204.

Jayanthi, S. S. (2013). Analisis Makna Pesan Generasi Penerus Pada Iklan Susu Nutrilon Royal Versi "Life Starts Here”. Skripsi. Bandar Lampung: Jurusan Ilmu Komunikasi Fakultas Ilmu Sosial dan Ilmu Politik Universitas Lampung.

Kellner, D. (2009). In Budaya Media. Yogyakarta: Jalasutra.

Khasali, R. (2007). In Manajemen Periklanan: Konsep dan Aplikasinya di Indonesia. Jakarta: Pustaka Umum Grafiti.

Kismono, G. (2008). In Pengantar Bisnis. Yogyakarta: BPFE.

KLHK. (2017). Kementerian Lingkungan Hidup dan Kehutanan. Retrieved November 25, 2020, from http://www.menlhk.go.id

Kotler, P., \& Amstrong, G. (2016). In Prinsip-Prinsip Pemasaran. Jakarta: Erlangga.

Kotler, P., \& Keller, K. L. (2012). In Marketing Management. New Jersey: Pearson Prentice Hall, Inc.

Kriyantono, R. (2009). In Teknik Praktis Riset Komunikasi. Malang: Prenada Media Group.

Kuswandi, W. (2014). In Komunikasi Massa: Analisis Interaktif Budaya Massa. Jakarta: Rineka Cipta.

Littlejhon, S. W., \& Karen, A. F. (2009). In Teori Komunikasi: Theory of Human Communication. Jakarta: Penerbit Salemba Humanika.

Maulana, T. (2019). Analisis Semiotika Iklan National Geographic "Planet Or Plastic" dalam Menyikapi Pesan Tersembunyi Tentang Kepedulian Lingkungan Hidup. Skripsi. Bandung: Fakultas Ilmu Sosial dan Ilmu Politik Universitas Pasundan.

Mawardi, M. (2011). In Aksi Hijau di Kantor. Yogyakarta: Majelis Lingkungan Hidup PP Muhammadiyah.

Moleong, L. J. (2011). In Metodologi Penelitian Kualitatif. Bandung: PT. Remaja Rosdakarya. 
Website : http://sosial.unmermadiun.ac.id/index.php/sosial

Mulyana, D. (2010). In Komunikasi Efektif Suatu Pendekatan Lintas Budaya. Bandung: PT. Remaja Rosdakarya.

Najam, H. (2019). Pesan Moral Dalam Iklan Bukalapak Edisi “Bu Linda” Di Youtube (Analisis Semiotika Charles Sanders Pierce). Skripsi. Surabaya: Program Studi Ilmu Komunikasi Fakultas Dakwah dan Komunikasi Universitas Islam Negeri Sunan Ampel.

Neolaka, A. (2008). In Kesadaran Lingkungan (p. 41). Jakarta: PT Rin-eka Cipta.

Nielsen. (2017). Nielsen. Retrieved November 25, 2020, from http://www.nielsen.com

Noviani, R. (2002). ,Jalan Tengah Memahami Iklan, Antara Realitas, Representasi, dan Simulasi. Yogyakarta: Pustaka Pelajar.

Nugroho, P. A. (2019). In Interpretasi Wisata Alam: Perencanaan Interpretasi Wisata Alam Terpandu dan Mandiri. Yogyakarta: Deepublish.

Pawito. (2008). In Penelitian Komunikasi Kualitatif. Yogyakarta: Pelangi Aksara.

Piliang, Y. (2003). In Hipersemiotika Tafsir Cultural Studie Atas Matinya Makna. Yogyakarta: Jalasutra.

Putra, D. R. (2017). Analisis Semiotika Roland Barthes Mengenai Kritik Sosial Terhadap Pencemaran Lingkungan Dalam Video Klip Lagu "Up \& Up" Karya Band Coldplay. Skripsi. Kupang: Fakultas Ilmu Sosial dan Ilmu Politik Universitas Katolik Widya M.

Rachmani, N. (2015). Analisis Semiotika Iklan Ades Versi "Langkah Kecil Memberikan Perubahan" Dalam Menyingkap Pesan Tersembunyi Tentang Kepedulian Lingkungan Hidup. e-Journal Ilmu Komunikasi., 3(2), 432-446.

Rakhmat, J. (2011). In Psikologi Komunikasi. Bandung: PT Remaja Rosdakarya.

Roman, Maas, \& Nisenholtz. (2005). In How To Advertise.

Saladin, D. (2011). In Intisari Pemasaran dan Unsur-Unsur Pemasaran. Bandung: Linda Karya.

Shimp, T. (2003). In Periklanan Promosi Aspek Tambahan. Jakarta: Erlangga.

Sobur, A. (2013). In Semiotika Komunikasi. Bandung: Remaja Rosdakarya.

Srinati, D. (2016). In Popular Culture (Budaya Populer): Pengantar Menuju Budaya Populer. Jakarta: Narasi.

Sugiyono. (2016). In Metode Penelitian: Pendekatan Kuantitatif, Kualitatif, dan R\&D. Bandung: Alfabeta.

Supardi, I. (2003). In Lingkungan Hidup dan Kelestariannya. Bandung: PT Alumni.

Sutanto, J. (2019). Harian Jogja. Retrieved Januari 16, 2021, from http://www.jogjapolitan.harianjogja.com

Syaprillah, A. (2018). In Buku Ajar Mata Kuliah Hukum Lingkungan. Yogyakarta: Deepublish.

Syuropati, M. A., \& Soebachman, A. (2012). In 7 Teori Sastra Kontemporer \& 17 Tokohnya. Yogyakarta: IN AzNA Books.

Tinarbuko, S. (2012). In M. Nasrudin (Ed.), Semiotika Komunikasi Visual. Yogyakarta: Jalasutra.

Unknown. (2011). Teknik Pengambilan Gambar Atau Video. Retrieved Januari 25, 2021, from http://bopfive5.blogspot.com/2011/05/teknik-pengambilan-gambar-atau-video.html

Wahyuningsih, S. (2019). In Film \& Dakwah Memahami Representasi Pesan-Pesan Dakwah dalam Film Melalui Analisis Semiotik. Surabaya: Media Sahabat Cendekia.

Wibowo, I. (2011). In Semiotika Komunikasi: Aplikasi Praktis Bagi Penelitian dan Skripsi Komunikasi. Jakarta: Mitra Wacana Media.

Wibowo, I. S. (2011). Semiotika Komunikasi Aplikasi Praktis Bagi Penelitian dan Skripsi Komunikasi. Jakarta: Mitra Wacana Media. 
Website : http://sosial.unmermadiun.ac.id/index.php/sosial

Widagdo. (1993). In Desain Teori dan Praktek : Seni Jurnal Pengetahuan dan Penciptaan Seni. Yogyakarta: BP ISI.

Yuniarto, B. (2018). In Membangun Kesadaran Warga Negara dalam Pelestarian Lingkungan. Yogyakarta: Deepublish. 